\title{
KOMBINASI METODE LOCAL BINARY PATTERN DAN K-NEAREST NEIGHBOR UNTUK IDENTIFIKASI LUBANG PADA JALAN ASPAL
}

\author{
Putra Prima Arhandi ${ }^{1}$, Mustika Mentari ${ }^{2}$, Fathur Romadhon ${ }^{3}$ \\ 1,2,3 Politeknik Negeri Malang \\ e-mail: putraprima@polinema.ac.id ${ }^{1}$, must.mentari@polinema.ac.id ${ }^{2}$, \\ fathurromadhon31@gmail.com ${ }^{3}$
}

\begin{abstract}
Abstrak
Kondisi jalan yang baik akan memudahkan segala aktivitas masyarakat. Terjadinya kerusakan pada jalan akan berakibat bukan hanya terhalangnya kegiatan ekonomi dan sosial namun akan berpengaruh pada keamanan dan kenyamanan pemakai jalan. Salah satu kendala utama yang menyebabkan lamanya perbaikan kerusakan jalan yaitu proses pendeteksian dan pencatatan kerusakan. Proses tersebut saat ini dilakukan secara manual dengan bantuan tenaga manusia. Karena proses pendeteksian dan pendataan masih dilakukan secara manual dengan tenaga manusia, waktu yang dibutuhkan relatif lama dan tingkat keakuratannya rendah. Oleh karena itu, pada penelitian ini dikembangkan sebuah sistem yang dapat menjadi alternatif Dinas Pembangunan Umum untuk mengidentifikasi lubang pada aspal sehingga dapat mempercepat proses perbaikan jalan. Sistem yang dikembangkan berhasil mengidentifikasi lubang pada jalan aspal menggunakan kombinasi metode Local Binary Pattern (LBP) dan K-Nearest Neighbor (KNN). Local Binary Pattern (LBP) untuk transformasi sebagai tahap awal ekstraksi ciri. Metode K- Nearest Neighbor (KNN) digunakan untuk klasifikasi citra jalan aspal berlubang atau tidak. Proses pengujian pada penelitian ini terdiri dari dua pengujian utama, yaitu pengujian unit dan pengujian akurasi. Pengujian unit dilakukan dengan black box testing. Pada pengujian akurasi diperoleh akurasi sebesar $96 \%$ dengan FAR sebesar $0 \%$ dan FRR sebesar $4,16 \%$. Pada proses perhitungan lubang pada aspal diperoleh akurasi yang sangat baik yaitu sebesar $97,74 \%$.
\end{abstract}

Kata kunci: Identifikasi Lubang Jalan Aspal, Local Binary Pattern, K-Nearest Neighbors

\begin{abstract}
Good road conditions will facilitate all community activities. Damage to roads will not only result in obstruction of economic and social activities but will also affect the safety and comfort of road users. One of the main obstacles that causes the length of time to repair road damage is the process of detecting and recording the damage. The process is currently carried out manually with the help of human labor, so the time required is relatively long and the level of accuracy is low. Therefore, in this study a system was developed that can help identify holes in the asphalt automatically so that it can speed up the road repair process. The system developed using a combination of the Local Binary Pattern (LBP) and K-Nearest Neighbor (KNN) methods has successfully identified holes on asphalt roads. Local Binary Pattern (LBP) for transformation as an initial stage of feature extraction. The K-Nearest Neighbor (KNN) method is used to classify images of asphalt roads with or without holes. Testing in this study was carried out in two ways, namely unit testing and accuracy testing. Unit testing is done by black-box testing. The accuracy obtained is $96 \%$ with FAR $0 \%$ and FRR $4.16 \%$. The results of the accuracy-test in this study have a very good value. The accuracy value obtained is $97.74 \%$.
\end{abstract}

Keywords : Asphalt Road Hole Identification, Local Binary Pattern, K-Nearest Neighbors

Diterima Redaksi: 10-01-2021 | Selesai Revisi: 07-03-2021 | Diterbitkan Online: 30-03-2021

DOI: https://doi.org/10.23887/janapati.v10i1.30999

\section{PENDAHULUAN}

Jalan merupakan sarana transportasi darat yang berperan penting dan paling sering digunakan untuk segala aktivitas masyarakat baik dalam mengadakan hubungan perekonomian maupun kegiatan sosial lainnya
[1]. Sehingga kondisi jalan yang baik akan memudahkan segala aktivitas tersebut. Lain halnya jika terjadi kerusakan pada jalan akan berakibat bukan hanya terhalangnya kegiatan ekonomi dan sosial namun akan berpengaruh pada keamanan dan kenyamanan pemakai 
jalan. Banyak pengemudi menganggap lubang sebagai bahaya saat mengemudi dan tidak hanya merusak mobil, tetapi bahkan bisa menyebabkan kecelakaan. Setiap kali pengemudi memperlambat kendaraannya untuk menghindari adanya lubang, ada kemungkinan terjadi tabrakan dengan kendaraan yang dibelakang, dimana pengemudi itu tidak tahu adanya lubang [1], [2].

Dinas Pekerjaan Umum mengungkapkan, proses perbaikan jalan dilakukan melalui tiga tahap, yaitu pencatatan, lelang projek, dan perbaikan. Salah satu kendala yang menyebabkan lamanya perbaikan kerusakan jalan yaitu proses pencatatan. Pada proses ini, dilakukan pendeteksian dan pendataan tiap-tiap kerusakan. Proses tersebut saat ini dilakukan secara manual dengan bantuan tenaga manusia. Karena proses pendeteksian dan pendataan masih dilakukan secara manual dengan tenaga manusia, waktu yang dibutuhkan relatif lama dan tingkat keakuratannya rendah. Proses tersebut bisa memakan waktu dua pekan untuk jalan sepanjang 1 kilometer [3]. Oleh karena itu, sangat penting bagi Pekerja Dinas Pekerjaan Umum untuk mengevaluasi proses pendeteksian dan pendataan, agar didapat solusi yang membutuhkan waktu relatif cepat dan tingkat keakuratan yang tinggi.

Koch dan Brilakisb mengungkapkan bahwa lubang jalan memiliki beberapa ciri yaitu secara visual lubang jalan memiliki ciri nampak lebih gelap jika dibandingkan dengan area sekitarnya dan teksturnya cenderung lebih kasar dibandingkan tekstur jalan di sekeliling lubang [2].

Dalam penelitian dikembangkan sebuah sistem untuk mengidentifikasi lubang pada jalan aspal. Sistem ini menggunakan metode Local Binary Pattern (LBP) untuk transformasi sebagai tahap awal ekstraksi ciri dan menggunakan metode ektraksi ciri statistik. LBP adalah metode analisis tekstur yang menggunakan model statistika dan struktur [4]-[6]. LBP bekerja dengan melakukan pemberian label pixel pada suatu citra berdasarkan thresholding ketetanggaan dari setiap pixel dan merepresentasikannya dalam bentuk biner [7].

Pada penelitian Mahardika dkk telah dilakukan identifikasi lubang pada jalan aspal dengan judul "Sistem Temu Kembali Citra Lubang Jalan Aspal Berdasarkan Tingkat Kerusakan Menggunakan Ekstraksi Fitur Gray Level Co-occurrence Matrix" [8]. Penelitian tersebut membahas tentang pengolah citra jalan aspal berlubang menggunakan CBIR dengan klasifikasi menggunakan metode Manhattan distance. Hasil dari penelitian tersebut memiliki nilai akurasi yang masih rendah yaitu $44,77 \%$ dan nilai MAP 0,558. Akurasi yang rendah tersebut disebabkan karena nilai tekstur pada tingkat kerusakan yang berbeda memiliki kemiripan. Penelitian tersebut belum membahas analisa tentang menentukan luas lubang. Hasil dari LBP ini akan diproses pada ekstraksi ciri statistik yang terdiri dari dua yaitu ekstraksi ciri statistic orde pertama dan orde kedua [8], sehingga menghasilkan vektor ciri yang dijadikan masukan pada klasifikasi citra dengan menggunakan metode $K$ - Nearest Neighbor (KNN) untuk diklasifikasikan ke dalam kelas citra jalan aspal berlubang atau tidak. KNN adalah metode klasifikasi untuk kumpulan data berdasarkan data pembelajaran yang telah diklasifikasikan sebelumnya. Algoritma KNN merupakan metode supervised learning yang efektif digunakan untuk melakukan klasifikasi data berukuran besar [9]. Proses dilanjutkan dengan melakukan segmentasi untuk memisahkan area lubang jalan dengan area sekitarnya, sehingga citra siap dianalisis untuk menghitung jumlah piksel citra guna mengetahui luas lubang pada jalan. Pada beberapa kasus, ekstraksi orde pertama tidak lagi dapat digunakan untuk mengenali perbedaan antar citra, oleh karena itu dibutuhkan pengambilan ciri statistik orde dua atau disebut juga dengan Gray Level Co-occurrence Matrix (GLCM). Salah satu teknik untuk memperoleh ciri statistik orde dua adalah dengan menghitung probabilitas hubungan ketetanggaan antara dua piksel pada jarak dan orientasi sudut tertentu [10].

\section{METODE}

Tahapan pengembangan sistem pada penelitian ini menggunakan metodologi waterfall yang meliputi Studi literatur, Perancangan Sistem, Analisa Sistem, Pengumpulan Data, Pemrograman Sistem dan Pengujian.

\section{Perancangan Sistem Identifikasi Lubang Menggunakan Kombinasi Metode LBP dan KNN}

Pada Gambar 1 dan Gambar 2 dapat dilihat alur proses metode LBP dan KNN dalam melakukan identifikasi lubang pada jalan aspal. Gambar 1 menunjukkan proses training data dari sistem identifikasi lubang. Sedangkan alur proses testing dapat diligat pada Gambar 2.Proses training diawali dengan data latih berupa citra jalan. Kemudian citra jalan ini masing-masing akan di resize sehingga memiliki ukuran yang sama satu sama lain. Kemudian citra tersebut akan diproses dengan metode LBP. Selanjutnya untuk memperoleh ekstraksi fitur maka hasil dari LBP dilanjutkan pada proses perhitungan dengan metode ekstraksi fitur GLCM. Pada proses ini didapatkan hasil 
data latih yang siap diproses ada tahap klasifikasi

Gambar 2 menunjukkan alur proses testing yang memiliki tahapan sama persis dengan Gambar 1. Hanya saja data yang diproses pada kedua tahap ini berbeda. Hasil ekstraksi fitur menggunakan GLCM pada data latih dan data uji dieksekusi pada tahap klasifikasi menggunakan metode KNN.

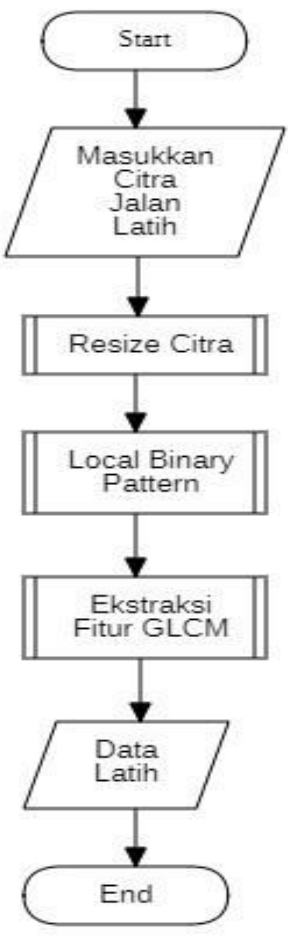

Gambar 1. Alur Sistem Proses Training

\section{Pengumpulan dan Pengolahan Data Citra Jalan Aspal}

\section{a. Metode Pengumpulan Data}

Citra jalan aspal diambil dengan kamera menghadap ke permukaan jalan dengan sudut $90^{\circ}$, dengan jarak yang sudah ditentukan. Perangkat yang digunakan adalah kamera Canon EOS D3200. Kamera dapat dikonfigurasikan pada kendaraan mobil berjenis minibus pada Gambar 1. Kondisi ideal pada skenario akuisisi data ini juga menempatkan lampu sorot penerang yang diposisikan menyamping di bagian bawah kendaraan, menghadap ke permukaan jalan yang disorot oleh kamera. Penempatan lampu ini bertujuan untuk meningkatkan brightness pada citra, meningkatkan contrast dari bayangan dan tekstur pada lubang. Selain itu dapat pula menghilangkan iluminasi cahaya dan / atau bayangan objek lainnya akibat sinar matahari, sehingga meningkatkan akurasi segmentasi pada citra hasil akuisisi [11].

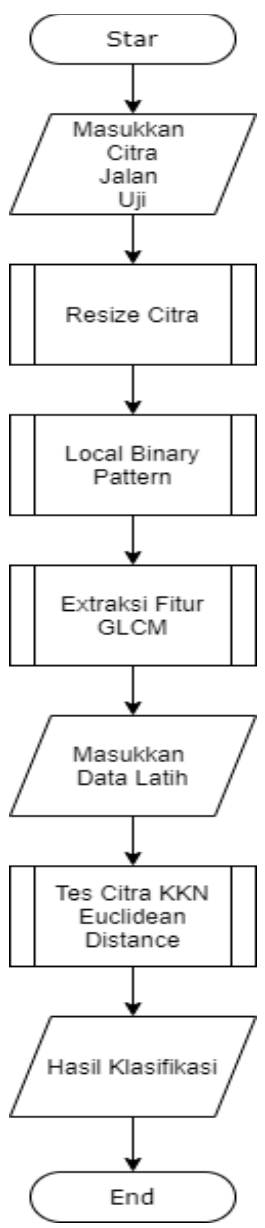

Gambar 2. Alur Sistem Proses Testing

Spesifikasi hasil citra yang diperolah dari pengambilan data menggunakan perangkat yang telah dijelaskan sesuai Gambar 3 yaitu, ukuran citra memiliki resolusi 2264 x 1968 pixel, jadi jumlah pixel total sama dengan 4.455.552. Hasil akuisisi citra yang telah dikumpulkan dapat dilihat pada Gambar 4a, yang merupakan foto jalan aspal berlubang. Gambar tersebut diambil dengan kamera yang telah disetting ISO 100, aperture f/11, dan shutter speed 1/1.000. 


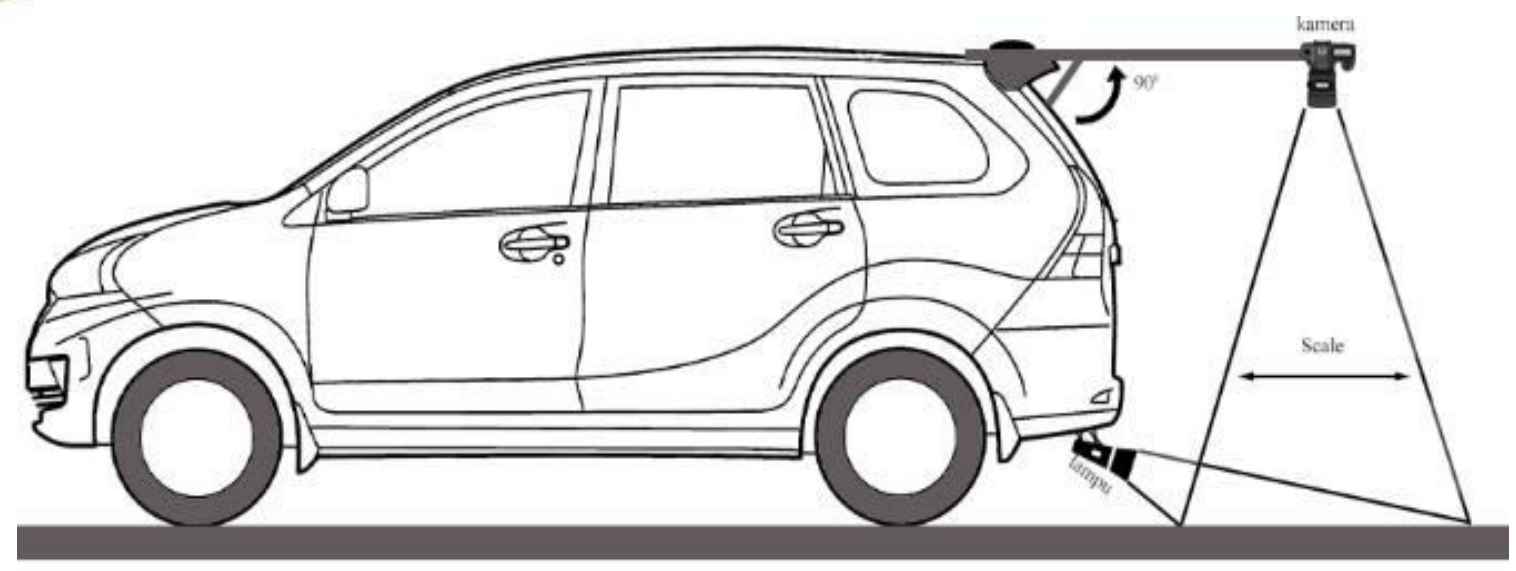

Gambar 3. Penempatan Perangkat Keras Akuisisi Data

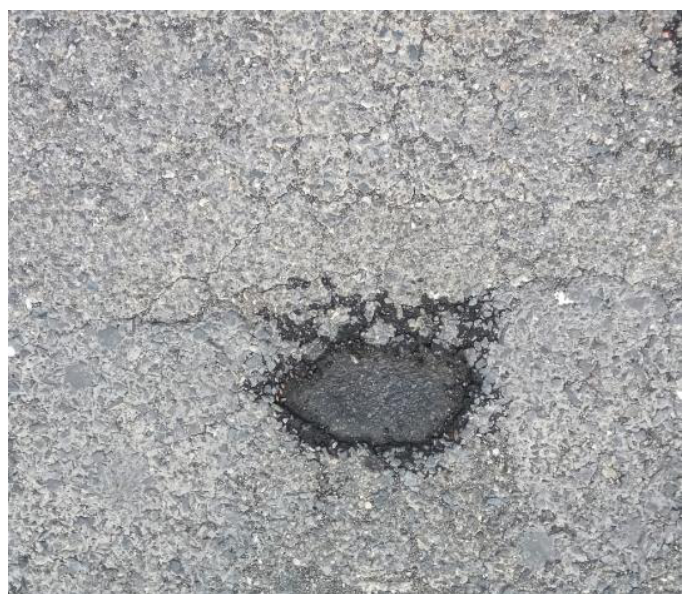

a. Citra Jalan Asli

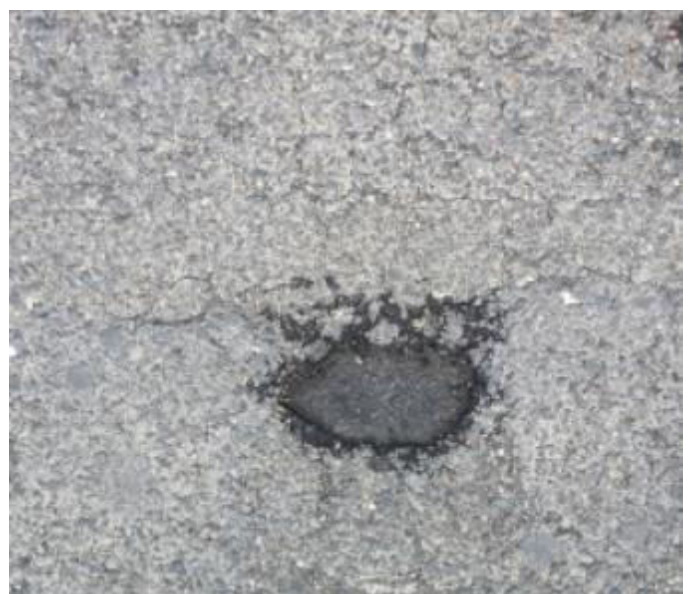

b. Citra Jalan Hasil Resize

Gambar 4. Citra Original dan Hasil Resize Citra Jalan Aspal

Jumlah data training dan data testing total adalah 120 citra jalan aspal yang terdiri 70 citra jalan aspal berlubang dan 50 citra jalan aspal tidak lubang. Jumlah data training sebanyak 96 citra terdiri dari 58 citra jalan aspal lubang, 38 citra jalan aspal tidak berlubang, sedangkan jumlah data testing sebanyak 24 citra aspal jalan terdiri dari 12 citra aspal jalan berlubang dan 12 citra aspal jalan tidak berlubang.

\section{b. Metode Pengolahan Data Citra}

Data citra jalan beraspal yang masih berupa citra warna, sebelum dilakukan ekstraksi fitur dengan LBP maka data citra hasil resize yang ditunjukkan pada Gambar 4b, dengan ukuran $283 \times 246$ dikonvesi kedalam format grayscale untuk memudahkan proses pengolahan citra selanjutnya. Resize tersebut dilakukan untuk mempercepat dan memudahkan proses perhitungan [12]. Fungsi ini menghitung nilai keabuan tiap piksel citra grayscale dari nilai intensitas komponen warna dasar (red, green dan blue) pixel pada citra RGB, sesuai dengan persamaan (1) [13].

Nilai keabuan $=0,2989 * \mathrm{R}+0,5870 * \mathrm{G}+0,1140 * \mathrm{~B}$

Kemudian dilakukan transformasi Local Binary Pattern (LBP) Gambar 5 LBP yang digunakan pola ketetanggan sirkuler. Caranya hitung selisih intensitas pada titik pusat dengan titik tetangga, jika hasil selisih besar dari titip pusat, maka diberi nilai 1 dan sebaliknya. Kemudian nilai disusun searah dengan jarum jam.

Gambar 5 samapi dengan Gambar 11 menjelaskan tentang proses ekstraksi dengan rincian sebagai berikut : 
1) Pada Gambar 5 sampai Gambar 11 akan terdapat perbedaan warna cell pada excel dengan rincian berikut :

a. Warna cell abu-abu :

Titik awal dimulai menghitung selisih intesitas pada titik pusat dengan titik tentangga.

b. Warna cell peach :

Titik selanjutnya mengihtung selisih intesitas pada titik pusat dengan titik tentangga

c. Warna cell merah :

Titik Pusat

2) Pada Gambar 6 Nilai pixel dari citra grayscale dipecah kebeberapa region matrix $3 \times 3$.

3) Nilai pixel citra yang telah dipecah kedalam beberapa bentuk region matrix $3 \times 3$ pixel dibandingkan ke setiap nilai threshold dari setiap region matrix. pada matrix tersebut yang dinyatakan sebagai nilai threshold adalah nilai pixel yang berada di tengah, kemudian nilai pixel tetangga yang lebih kecil dari nilai threshold tersebut akan dinyatakan dengan nilai biner 0 dan nilai pixel yang lebih besar atau sama dengan nilai threshold akan dinyatakan dengan nilai biner 1, hingga didapatkan matrix biner. Selanjutnya nilai biner yang dihasilkan dituliskan kedalam bentuk string biner dengan cara circular dari kanan ke kiri, operasi tersebut diterapkan ke setiap bagian region citra sebagaimana dijelaskan sebelumnya.

4) Pada Gambar 7 dari region 1 didapat nilai pixel threshold sebesar 30, kemudian dimulai perbandingan dengan nilai pixel tetangga dari nilai pojok kiri atas yang bernilai 31, dihasilkan nilai bit 1 karena nilai pixel tetangga lebih besar dari nilai pixel threshold. Selanjutnya lakukan perbandingan searah jarum jam, setelah selesai melakukan perbandingan urutkan nilai bit sesuai bobot yang ditentukan, maka akan didapat satu set nilai biner yaitu 11110011, nilai biner tersebut akan dikonversi menjadi nilai desimal untuk mengganti nilai tengah pixel, hasil konversi yaitu 207. Seperti yang sudah dijelaskan sebelumnya bahwa citra akan dibagi menjadi beberapa region.

5) Seperti contoh yang disajikan berikut satu citra akan dibagi menjadi 4 region dengan ukuran yang sama. Setiap region memiliki perlakuan dan proses yang sama dengan region 1 yang telah dijelaskan. Region 2 pada Gambar 8 menghasilkan nilai konversi yaitu 3, region 3 pada Gambar 9 dengan hasil konversi 143 , dan region 4 pada Gambar 10 dengan hasil konversi 31.

6) Pada Gambar 11 setiap string biner yang hasilkan akan dilakukan penyatuan kembali untuk mendapatkan tekstur citra secara keseluruhan.

\begin{tabular}{|c|c|c|}
\hline 31 & 35 & 36 \\
\hline 39 & 30 & 35 \\
\hline 43 & 29 & 29 \\
\hline \multicolumn{3}{|c|}{ Greyscale } \\
\hline
\end{tabular}
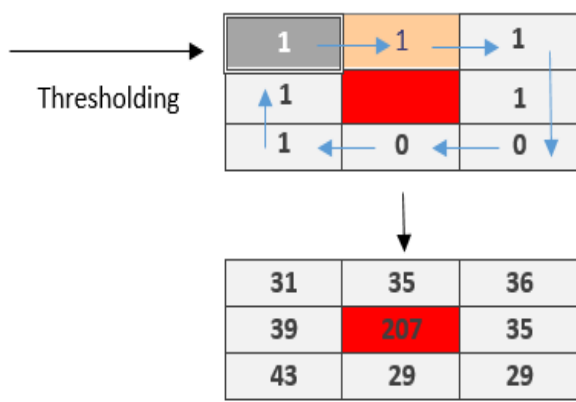

\begin{tabular}{|c|c|c|c|c|c|c|c|}
\hline \multicolumn{2}{|l|}{ Binner } & \multirow[b]{2}{*}{1} & \multirow[b]{2}{*}{1} & \multirow[b]{2}{*}{0} & \multirow[b]{2}{*}{0} & \multirow[b]{2}{*}{1} & \multirow[b]{2}{*}{1} \\
\hline 1 & 1 & & & & & & \\
\hline $1 \times 1$ & $1 \times 2$ & $1 \times 4$ & $1 \times 8$ & $0 \times 16$ & $0 \times 32$ & $1 \times 64$ & $1 \times 128$ \\
\hline 1 & 2 & 4 & 8 & 0 & 0 & 64 & 128 \\
\hline Desimal & & & & & & & \\
\hline
\end{tabular}

Gambar 5. Operasi dasar LBP 


\begin{tabular}{|l|l|l|l|}
\hline 31 & 35 & 36 & 19 \\
\hline 39 & 30 & 35 & 18 \\
\hline 43 & 29 & 29 & 17 \\
\hline 16 & 15 & 14 & 11 \\
\hline
\end{tabular}

\begin{tabular}{|l|l|l|l|}
\hline $\mathbf{3 1}$ & $\mathbf{3 5}$ & $\mathbf{3 6}$ & $\mathbf{1 9}$ \\
\hline $\mathbf{3 9}$ & 30 & $\mathbf{3 5}$ & 18 \\
\hline $\mathbf{4 3}$ & $\mathbf{2 9}$ & $\mathbf{2 9}$ & 17 \\
\hline 16 & 15 & 14 & 11 \\
\hline
\end{tabular}

\begin{tabular}{|l|l|l|l|}
\hline 31 & 35 & 36 & 19 \\
\hline 39 & 30 & 35 & 18 \\
\hline 43 & 29 & 29 & 17 \\
\hline 16 & 15 & 14 & 11 \\
\hline
\end{tabular}

\begin{tabular}{|l|l|l|l|}
\hline 31 & 35 & 36 & 19 \\
\hline $\mathbf{3 9}$ & $\mathbf{3 0}$ & $\mathbf{3 5}$ & 18 \\
\hline $\mathbf{4 3}$ & 29 & $\mathbf{2 9}$ & 17 \\
\hline $\mathbf{1 6}$ & $\mathbf{1 5}$ & $\mathbf{1 4}$ & 11 \\
\hline
\end{tabular}

\begin{tabular}{|l|l|l|l|}
\hline 31 & 35 & 36 & 19 \\
\hline 39 & $\mathbf{3 0}$ & $\mathbf{3 5}$ & $\mathbf{1 8}$ \\
\hline 43 & $\mathbf{2 9}$ & 29 & $\mathbf{1 7}$ \\
\hline 16 & $\mathbf{1 5}$ & $\mathbf{1 4}$ & $\mathbf{1 1}$ \\
\hline
\end{tabular}

Gambar 6. Nilai Pixel Citra Grayscale dan Pembagian Region

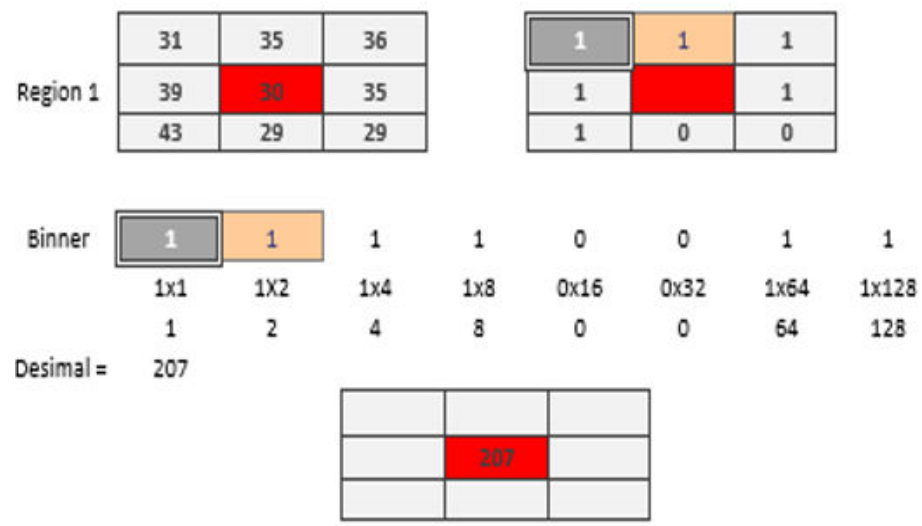

Gambar 7. Region 1 Matrix $3 \times 3$ dan Matrix biner dari citra

\begin{tabular}{|c|c|c|c|}
\hline \multirow{3}{*}{ gion 2} & 35 & 36 & 19 \\
\hline & 30 & 35 & 18 \\
\hline & 29 & 29 & 17 \\
\hline
\end{tabular}

\begin{tabular}{|l|l|l|}
\hline 1 & 1 & 0 \\
\hline 0 & & 0 \\
\hline 0 & 0 & 0 \\
\hline
\end{tabular}

Binn

\begin{tabular}{c|ccccccc|}
\hline 1 & 1 & 0 & 0 & 0 & 0 & 0 & 0 \\
\cline { 1 - 1 } $1 \times 1$ & $1 \times 2$ & $0 \times 4$ & $0 \times 8$ & $0 \times 16$ & $0 \times 32$ & $0 \times 64$ & $0 \times 128$ \\
1 & 2 & 0 & 0 & 0 & 0 & 0 & 0
\end{tabular}

Desimal $=3$

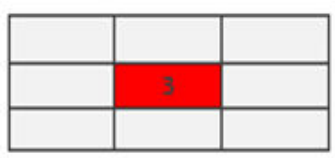

Gambar 8. Region 2 Matrix 3×3 dan Matrix biner dari citra 


\begin{tabular}{|c|c|c|c|}
\hline \multirow{3}{*}{ Region 3} & 39 & 30 & 35 \\
\hline & 43 & 29 & 29 \\
\hline & 16 & 15 & 14 \\
\hline
\end{tabular}

\begin{tabular}{|l|l|l|}
\hline 1 & 1 & 1 \\
\hline \hline 1 & & 1 \\
\hline 0 & 0 & 0 \\
\hline
\end{tabular}

Binner

\begin{tabular}{|c|ccccccc}
\hline 1 & 1 & 1 & 1 & 0 & 0 & 0 & 1 \\
\cline { 1 - 1 } & $1 \times 2$ & $1 \times 4$ & $1 \times 8$ & $0 \times 16$ & $0 \times 32$ & $0 \times 64$ & $1 \times 128$ \\
1 & 2 & 4 & 8 & 0 & 0 & 0 & 128 \\
143 & & & & & & &
\end{tabular}

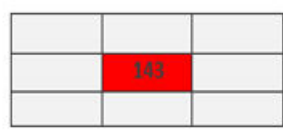

Gambar 9. Region 3 Matrix 3x3 dan Matrix biner dari citra

\begin{tabular}{|c|c|c|c|}
\hline \multirow{3}{*}{ Region 4} & 30 & 35 & 18 \\
\hline & 29 & 23 & 17 \\
\hline & 15 & 14 & 11 \\
\hline
\end{tabular}

\begin{tabular}{|l|l|l|}
\hline \hline 1 & 1 & 0 \\
\hline \hline 1 & & 0 \\
\hline 0 & 0 & 0 \\
\hline
\end{tabular}

Binner

\begin{tabular}{|c|c|c|c|c|c|c|c|}
\hline 1 & 1 & 0 & 0 & 0 & 0 & 0 & 1 \\
\hline $1 \times 1$ & $1 \times 2$ & $0 \times 4$ & $0 \times 8$ & $0 \times 16$ & $0 \times 32$ & $0 \times 64$ & $1 \times 128$ \\
\hline 1 & 2 & 0 & 0 & 0 & 0 & 0 & 128 \\
\hline
\end{tabular}

Desimal $=131$

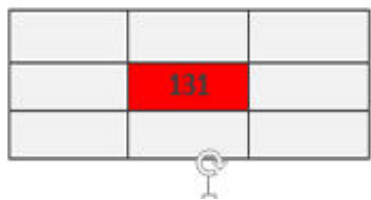

Gambar 10. Region 4 Matrix 3x3 dan Matrix biner dari citra

\begin{tabular}{|l|l|l|l|}
\hline 31 & 35 & 36 & 19 \\
\hline 39 & 30 & 35 & 18 \\
\hline 43 & 29 & 29 & 17 \\
\hline 16 & 15 & 14 & 11 \\
\hline
\end{tabular}

$=$\begin{tabular}{|l|l|l|l|}
\hline 31 & 35 & 36 & 19 \\
\hline 39 & 207 & 3 & 18 \\
\hline 43 & 143 & 131 & 17 \\
\hline 16 & 15 & 14 & 11 \\
\hline
\end{tabular}

Gambar 11. Tekstur citra keseluruhan

Tekstur citra yang didapatkan selanjutnya akan diekstraksi menggunakan ekstraksi fitur GLCM. ekstraksi fitur GLCM akan menghasilkan nilai attribut dari citra yang selanjutnya dapat digunakan untuk mengklasifikasikan citra berlubang atau tidak. Langkah Pertama untuk menghitung nilai dari GLCM yaitu menentukan arah dan jarak yang akan digunakan untuk menghitung nilai citra. Selanjutnya menghitung jumlah pixel yang berpasangan yang terbentuk dan kemudian membentuk matrix GLCM. Matrix GLCM yang terbentuk selanjutnya dinormalisasi. Pada penelitian ini akan digunakan jarak $d=1$ dengan orientasi sudut $\theta=0^{\circ}$, Berikut proses perhitungan matrix cooccurrence dengan jarak $\mathrm{d}=1$ dan sudut $\theta=0^{0}$

Setelah didapatkan matrix GLCM maka kita dapat kemudian mencari parameter dari proses ekstraksi ciri, beberapa parameter ciri orde pertama, yaitu mean, skewness, variance, kurtosis, dan entropy. Dan parameter ekstraksi ciri orde kedua yaitu Angular Second Moment, Contrast, Correlation, Variance, Inverse Different Moment, dan Entropy [10]. Setelah dilakukan 
ekstraksi ciri lalu parameter didapat direpresentasikan ke dalam fitur dengan nilai tertentu sehingga dapat dikenali dan diinterpretasikan ke dalam kelas lubang atau bukan lubang dengan metode K-NN. Selanjutnya akan dilakukan proses untuk menghitung luas pada jalan berlubang.

Pada citra lubang jalan, kekasaran tekstur permukaan jalan seringkali mempersulit proses segmentasi, karena dengan adanya tekstur tersebut batasan daerah dengan keseragaman intensitas warna menjadi tidak jelas karena tekstur akan dianggap noise. Atas dasar itu metode-metode yang berbasis keseragaman intensitas warna berdasarkan daerah atau lokasi piksel seperti region-growing, split and merge, edge detection, dan clustering menjadi tidak optimal. Thresholding adalah salah satu metode segmentasi citra berdasarkan penerapan ambang batas terhadap nilai intensitas disetiap pixel. Dari masalah kondisi tekstur citra lubang diatas, metode Thresholding akan bekerja lebih optimal, karena tidak memperhatikan daerah atau lokasi pixel [14]. Nobuyuki Otsu mengenalkan metode untuk mengoptimalkan nilai ambang batas dengan melihat kemungkinan objek dan latar belakang melalui penyebaran intensitas pada histogram [13]. Selanjutnya akan dilakukan operasi morfologi yaitu erosi dan dilasi. Proses erosi diterapkan pada citra biner jalan beraspal untuk mengurangi/menghilangkan objek-objek yang tidak diperlukan, proses selanjutnya dilakukan proses dilasi pada citra-citra tersebut [15]. Hal ini dimaksudkan agar bagian objek yang hilang akibat proses erosi dapat dikembalikan karena bagian objek tersebut termasuk pixel yang akan dihitung untuk mengetahui luas objek. Penghitungan jumlah pixel objek dilakukan pada citra hasil proses dilasi, pixel yang dihitung adalah pixel yang bernilai 1 (berwarna putih) setelah pixel putih diketahui jumlahnya kemuadian dikalikan dengan skala citra sebenarnya. Untuk menghitung luas objek citra (jalan beraspal) dalam satuan $\mathrm{m}^{2}$, diperlukan skala yang mewakili ukuran sebenarnya dari citra tersebut [15]. Setelah didapat luas melalui proses diatas, luas lubang akan dipakai untuk pendataan dalam proses pencatatan.

\section{Proses Pengujian}

Proses pengujian pada penelitian ini terdiri dari dua pengujian utama, yaitu pengujian unit dan pengujian akurasi. Pengujian unit ditujukan untuk memastikan bahwa setiap fungsi berjalan dengan benar sesuai dengan rancangan yang diharapkan dimana strategi pengujiannya menggunakan metode blackbox. Pengujian akurasi perhitungan diperlukan untuk menguji tujuan utama dari penelitian ini bahwa dengan menerapkan salah satu metode K-NN sebagai proses klasifikasi dengan menggunakan feature teksture LBP yang didapatkan dari jalan aspal dapat mengklasifikasikan citra jalan aspal tersebut menjadi lubang atau tidak dengan menggunakan persamaan (2), persamaan (3), dan persamaan (4).

$\mathrm{FAR}=\frac{\text { jumlah data jalan tidak berlubang terdete ksi berlubang }}{\text { jumlah data jalan berlubang terdeteksi tidak berlubang }} \times 100 \%$
$\mathrm{FRR}=\frac{\text { jumlah data jalan tidak berlubang terdeteksi berlubang }}{\text { jumlah data jalan berlubang terdeteksi tidak berlubang }} \times 100 \%$ (3)
akurasi sistem $=\frac{\text { jumlah data benar }}{\text { jumlah data keseluruhan }} \times 100 \%$
Nilai $\mathrm{K} \quad$ merupakan jumlah titik pembanding yang akan dibandingkan dengan titik uji. Pada $\mathrm{K}=1$, akan dicari jarak terdekat dengan nilai titik uji. Untuk Nilai K lebih dari satu, selanjutnya akan dilakukan voting berdasarkan mayoritas keberadaan kelasnya. Untuk itu, besar nilai $\mathrm{K}$ harus merupakan bilangan ganjil, supaya dapat dilakukan voting berdasarkan mayoritas keberadaannya didalam suatu kelas [16].

\section{HASIL DAN PEMBAHASAN}

\section{Hasil Citra Jalan pada Setiap Tahapan Metode}

Sesuai tahapan metode yang sudah dijelaskan pada metode, dapat dilihat beberapa perubahan wujud citra jalan mulai dari citra original yang ditunjukkan pada

Gambar 12a, kemudian citra greyscale pada Gambar 12b, citra erosi pada Gambar 12c, dan citra Dilasi pada Gambar 12d.

Selain itu juga dapat dilihat pada Gambar $12 \mathrm{e}$ untuk citra jalan aspal yang dikenali tidak sesuai dengan kelas yang ada pada penelitian ini, dan ada juga yang dikenali sesuai dengan kelasnya seperti Gambar $12 f$.

\section{Pengaruh nilai $K$ pada Hasil $K N N$ Euclidean Distance \\ Nilai $\mathrm{K}$ yang digunakan dalam K-NN} adalah 1, 3, 5, 7, 9 11, dan 13. Hasil uji klasifikasi citra menggunakan aplikasi dari 130 citra, perbandingan data latih dan data uji sebesar $90 \%$ data latih dan $10 \%$ data uji dengan nilai $\mathrm{K}=1$ pada tabel $1, \mathrm{~K}=3$ pada tabel $3, \mathrm{~K}=5$ pada tabel $4, \mathrm{~K}=7$ pada tabel $5, \mathrm{~K}=11$ pada tabel $6, \mathrm{~K}=13$ pada tabel $7, \mathrm{~K}=13$ pada tabel 7. 
Seperti terlihat pada Tabel 1 sampai Tabel 5, hasil klasifikasi dengan perubahan nilai $\mathrm{K}$ Menghasilkan akurasi yang tidak jauh berbeda. Pengujian Akurasi system

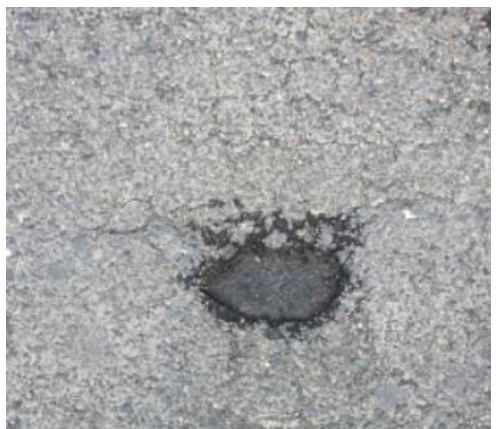

a. Citra jalan original

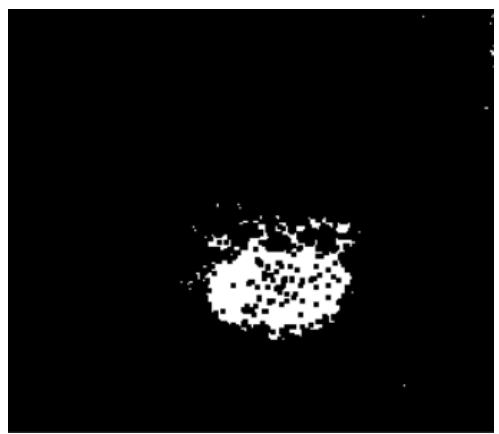

c. Citra jalan Erosi

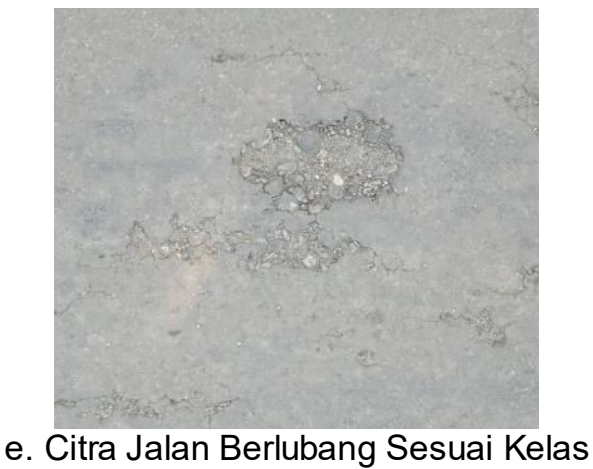

Gambar 12. Perubahan Citra Jalan Pada Tiap Tahapan Metode

melihat sejauh mana sistem melakukan kesalahan dalam menerima masukan, dimana citra jalan yang seharusnya terdeteksi tidak berlubang namun terdeteksi berlubang oleh sistem. Sedangkan FRR menunjukkan sistem melakukan kesalahan dalam menolak masukan, dimana citra jalan yang seharusnya menggunakan False Acceptance Rate (FAR), False Rejection Rate (FRR), dan akurasi sistem. FAR berguna untuk

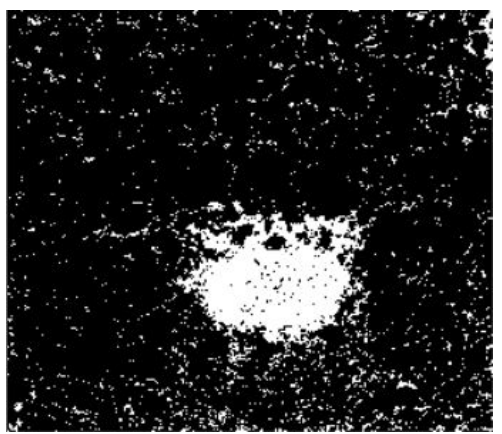

b. Citra jalan Greyscale

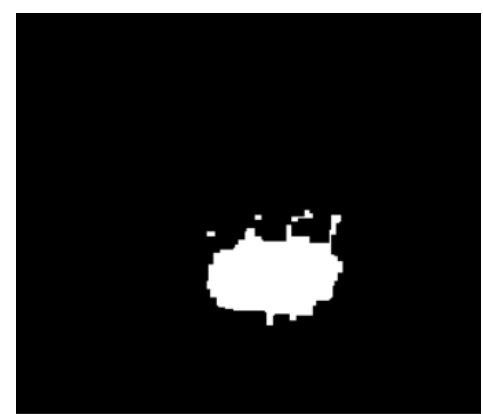

d. Citra jalan Dilasi

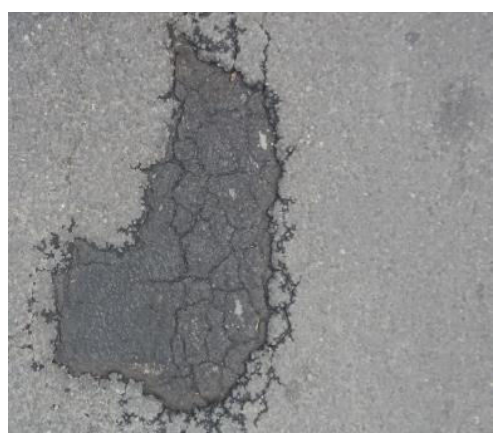

f. Citra Jalan Berlubang Tidak Sesuai Kelas

Tabel 1. Tingkat akurasi $\mathrm{KNN}$ dengan $\mathrm{K}=1$

\begin{tabular}{llllll}
\hline Kriteria Jalan & Jumlah & Sesuai & Tidak & FAR \& FRR & Tingkat \\
\hline
\end{tabular}




\begin{tabular}{|c|c|c|c|c|c|}
\hline & Sampel & & Sesuai & & Akurasi \\
\hline Jalan Berlubang & 12 & 11 & 1 & $\mathrm{FRR}=4,16 \%$ & $92 \%$ \\
\hline Jalan Tidak Berlubang & 12 & 11 & 1 & $F A R=4,16 \%$ & $92 \%$ \\
\hline Total Akurasi & 24 & 22 & 2 & & $92 \%$ \\
\hline
\end{tabular}

rasi $\mathrm{KNN}$ dengan $\mathrm{K}=3$

\begin{tabular}{cccccc}
\hline Kriteria Jalan & $\begin{array}{c}\text { Jumlah } \\
\text { Sampel }\end{array}$ & Sesuai & $\begin{array}{c}\text { Tidak } \\
\text { Sesuai }\end{array}$ & FAR \& FRR & $\begin{array}{c}\text { Tingkat } \\
\text { Akurasi }\end{array}$ \\
\hline Jalan Berlubang & 12 & 10 & 2 & FRR $=8,33 \%$ & $83 \%$ \\
Jalan Tidak Berlubang & 12 & 11 & 1 & FAR $=4,16 \%$ & $92 \%$ \\
Total Akurasi & 24 & 21 & 3 & & $88 \%$ \\
\hline
\end{tabular}

Tabel 3. Tingkat akurasi KNN dengan $\mathrm{K}=5$

\begin{tabular}{lccccc}
\hline \multicolumn{1}{c}{ Kriteria Jalan } & $\begin{array}{c}\text { Jumlah } \\
\text { Sampel }\end{array}$ & Sesuai & $\begin{array}{c}\text { Tidak } \\
\text { Sesuai }\end{array}$ & FAR \& FRR & $\begin{array}{c}\text { Tingkat } \\
\text { Akurasi }\end{array}$ \\
\hline Jalan Berlubang & 12 & 11 & 1 & FRR $=4,16 \%$ & $92 \%$ \\
Jalan Tidak Berlubang & 12 & 12 & 0 & FAR $=0 \%$ & $100 \%$ \\
Total Akurasi & 24 & 23 & 1 & & $96 \%$ \\
\hline
\end{tabular}

\begin{tabular}{lccccc}
\hline \multicolumn{1}{c}{ Kriteria Jalan } & $\begin{array}{c}\text { Jumlah } \\
\text { Sampel }\end{array}$ & Sesuai & $\begin{array}{c}\text { Tidak } \\
\text { Sesuai }\end{array}$ & FAR \& FRR & $\begin{array}{c}\text { Tingkat } \\
\text { Akurasi }\end{array}$ \\
\hline Jalan Berlubang & 12 & 11 & 1 & FRR $=4,16 \%$ & $92 \%$ \\
Jalan Tidak Berlubang & 12 & 12 & 0 & FAR $=0 \%$ & $100 \%$ \\
Total Akurasi & 24 & 23 & 1 & & $96 \%$ \\
\hline
\end{tabular}

Tabel 4. Tingkat akurasi KNN dengan $\mathrm{K}=7$

\begin{tabular}{lccccc}
\hline \multicolumn{1}{c}{ Kriteria Jalan } & $\begin{array}{c}\text { Jumlah } \\
\text { Sampel }\end{array}$ & Sesuai & $\begin{array}{c}\text { Tidak } \\
\text { Sesuai }\end{array}$ & FAR \& FRR & $\begin{array}{c}\text { Tingkat } \\
\text { Akurasi }\end{array}$ \\
\hline Jalan Berlubang & 12 & 9 & 3 & FRR $=12,5 \%$ & $75 \%$ \\
Jalan Tidak Berlubang & 12 & 11 & 1 & FAR $=4,16 \%$ & $92 \%$ \\
Total Akurasi & 24 & 20 & 4 & & $83 \%$ \\
\hline
\end{tabular}

Tabel 5. Tingkat akurasi KNN dengan $\mathrm{K}=9$

\begin{tabular}{lccccc}
\hline \multicolumn{1}{c}{ Kriteria Jalan } & $\begin{array}{c}\text { Jumlah } \\
\text { Sampel }\end{array}$ & Sesuai & $\begin{array}{c}\text { Tidak } \\
\text { Sesuai }\end{array}$ & FAR \& FRR & $\begin{array}{c}\text { Tingkat } \\
\text { Akurasi }\end{array}$ \\
\hline Jalan Berlubang & 12 & 9 & 3 & FRR $=12,5 \%$ & $75 \%$ \\
Jalan Tidak Berlubang & 12 & 12 & 0 & FAR $=0 \%$ & $100 \%$ \\
Total Akurasi & 24 & 21 & 3 & & $88 \%$ \\
\hline
\end{tabular}

Tabel 6. Tingkat akurasi KNN dengan $\mathrm{K}=11$ 


\begin{tabular}{lccccc}
\hline \multicolumn{1}{c}{ Kriteria Jalan } & $\begin{array}{c}\text { Jumlah } \\
\text { Sampel }\end{array}$ & Sesuai & $\begin{array}{c}\text { Tidak } \\
\text { Sesuai }\end{array}$ & FAR \& FRR & $\begin{array}{c}\text { Tingkat } \\
\text { Akurasi }\end{array}$ \\
\hline Jalan Berlubang & 12 & 9 & 3 & FRR $=12,5 \%$ & $75 \%$ \\
Jalan Tidak Berlubang & 12 & 12 & 0 & FAR $=0 \%$ & $100 \%$ \\
Total Akurasi & 24 & 21 & 3 & & $88 \%$ \\
\hline
\end{tabular}

Tabel 7. Tingkat akurasi KNN dengan $\mathrm{K}=13$

Tabel 8. Perhitungan Luas Lubang

\begin{tabular}{|c|c|c|c|c|c|c|c|c|}
\hline \multirow[b]{2}{*}{ No } & \multicolumn{2}{|c|}{ Skala } & \multicolumn{2}{|c|}{ Piksel Putih } & \multicolumn{2}{|c|}{ Luas } & \multirow[b]{2}{*}{ Selisih } & \multirow[b]{2}{*}{ Akurasi } \\
\hline & $\begin{array}{l}\text { Sistem } \\
\left(\mathrm{cm}^{2}\right)\end{array}$ & $\begin{array}{c}\text { Manual } \\
\left(\mathrm{cm}^{2}\right)\end{array}$ & $\begin{array}{l}\text { Sistem } \\
\text { (piksel) }\end{array}$ & $\begin{array}{l}\text { Manual } \\
\text { (pikesl) }\end{array}$ & Sistem & Manual & & \\
\hline 1 & 0,16518 & 9,1706 & 17535 & 320 & 2896,56 & 2934,609 & 38,05208 & $98,70 \%$ \\
\hline 2 & 0,16518 & 9,1706 & 16918 & 311 & 2794,64 & 2852,0733 & 57,43686 & $97,90 \%$ \\
\hline 3 & 0,16518 & 9,1706 & 5831 & 110 & 963,20 & 1008,7719 & 45,56555 & $95,40 \%$ \\
\hline 4 & 0,16518 & 9,1706 & 2798 & 52 & 462,19 & 476,874 & 14,68031 & $96,90 \%$ \\
\hline \multirow[t]{2}{*}{5} & 0,16518 & 9,1706 & 7037 & 127 & 1162,42 & 1164,6662 & 2,244125 & $99,80 \%$ \\
\hline & \multicolumn{7}{|c|}{ Rata-rata Akurasi } & $97,74 \%$ \\
\hline
\end{tabular}

Tingkat Akurasi tertinggi didapat dari nilai $\mathrm{K} 5$ dan $\mathrm{K} 7$, dengan total akurasi sebesar $96 \%$ dengan FAR sebesar $0 \%$ dan FRR sebesar 4,16\%. Kesalahan klasifikasi oleh sistem terjadi karena citra tidak berlubang memiliki tekstur yang hampir sama dengan citra berlubang setelah citra melalui proses convert ke LBP sehingga memiliki variasi yang besar dan diklasifikasikan sebagai objek lubang. Dan sebaliknya citra berlubang memiliki tekstur yang hampir sama pula dengan citra tidak berlubang setelah citra melalui proses convert to LBP Sehingga memiliki variasi yang kecil dan diklasifikasikan sebagai objek bukan lubang.

\section{Perhitungan Luas Lubang}

Perhitungan luas lubang dapat dilihat pada tabel 8. Pada skenario diatas tahap awal yang dilakukan adalah citra menyediakan segmentasi manual sebagai pembanding terhadap hasil segementasi dari sistem. Jumlah luas lubang pada citra hasil segmentasi manual akan dibandingkan dengan jumlah luas yang tersegmentasi melalui sistem. Selisih jumlah luas tersebut kemudian akan dihitung untuk menentukan tingkat akurasi.

Pengujian pada skenario A menunjukkan bahwa rata-rata selisih antara segmentasi manual dengan hasil segmentasi sistem sebesar 31,59578. hal ini dipengaruhi oleh ketegasan batas dari lubang serta adanya objek lain di dalam lubang seperti genangan air, batu kerikil yang mempengaruhi nilai threshold.Dari hasil klasifikasi dengan perubahan nilai $\mathrm{K}$ dapat dilihat tingkat akurasi yang didapat tidak jauh berbeda.

Pengujian Akurasi sistem menggunakan False Acceptance Rate (FAR), untuk menghitung nilai FAR menggunakan persamaan (20), sedangkan untuk menghitung nilai FRR menggunakan persamaan (21), dan untuk menghitung Tingkat Akurasi menggunakan persamaan (22). Tingkat Akurasi tertinggi didapat dari nilai $\mathrm{K} 5$ dan $\mathrm{K}$ 7 , dengan total akurasi sebesar $96 \%$ dengan FAR sebesar $0 \%$ dan FRR sebesar 4,16\%. Kesalahan klasifikasi oleh sistem terjadi karena citra tidak berlubang memiliki tekstur yang hampir sama dengan citra berlubang setelah citra melalui proses convert ke LBP 
sehingga memiliki variasi yang besar dan diklasifikasikan sebagai objek lubang. Dan sebaliknya citra berlubang memiliki tekstur yang hampir sama pula dengan citra tidak berlubang setelah citra melalui proses convert ke LBP Sehingga memiliki variasi yang kecil dan diklasifikasikan sebagai objek bukan lubang.

\section{KESIMPULAN}

Berdasarkan hasil pengujian dengan perbandingan data training dan data testing sebesar $90 \%$ dan $10 \%$ dari 130 citra yang terdiri 70 lubang dan 50 bukan lubang didapat akurasi terbaik dari nilai $\mathrm{K} 5$ dan $\mathrm{K} 7$, dengan total akurasi sebesar $96 \%$ dengan FAR sebesar $0 \%$ dan FRR sebesar 4,16\%. Kesalahan klasifikasi oleh sistem terjadi karena citra tidak berlubang memiliki tekstur yang hampir sama dengan citra berlubang setelah citra melalui proses convert ke LBP sehingga memiliki variasi yang besar dan diklasifikasikan sebagai objek lubang. Dan sebaliknya citra berlubang memiliki tekstur yang hampir sama pula dengan citra tidak berlubang setelah citra melalui proses convert to LBP Sehingga memiliki variasi yang kecil dan diklasifikasikan sebagai objek bukan lubang. Berdasarkan hasil pengujian juga didapatkan rata-rata akurasi metode sebesar $97,74 \%$. Rata rata selisih luas perhitungan sistem dengan peritungan manual sebesar 31,59. Hasil ni dipengaruhi oleh ketegasan batas dari lubang pada jalan aspal serta adanya objek lain di dalam lubang seperti genangan air atau batu kerikil yang mempengaruhi nilai threshold. Pada penelitian lebih lanjut perlu dilakukan penambahan metode untuk menghitung kedalaman dari lubang jalan aspal untuk meningkatkan fitur sistem.

\section{REFERENSI}

[1] U. Bhatt, S. Mani, E. Xi, and J. Zico Kolter, "Intelligent Pothole Detection and Road Condition Assessment," Bloom. Data Good Exch. Conf., 2017.

[2] C. Koch and I. Brilakis, "Pothole detection in asphalt pavement images," Adv. Eng. Informatics, vol. 25, no. 3, pp. 507-515, Aug. 2011, doi: 10.1016/j.aei.2011.01.002.

[3] P. Hidayatullah et al., "Pendeteksian Lubang Di Jalan Secara Semi-Otomatis Semi-Automatic Pothole Detection," pp. 41-51.

[4] A. Kurniawardhani, N. Suciati, and I. Arieshanti, "Klasifikasi Citra Batik Menggunakan Metode Ekstraksi Ciri yang Invariant Terhadap Rotasi," JUTI J. IIm. Teknol. Inf., vol. 12, no. 2, p. 48, Jul. 2014, doi: 10.12962/j24068535.v12i2.a322.

[5] A. K. Bachchan, A. Gorai, and P. Gupta, "Automatic license plate recognition using local binary pattern and histogram matching," in Lecture Notes in Computer Science (including subseries Lecture Notes in Artificial Intelligence and Lecture Notes in Bioinformatics), 2017, vol. 10362 LNCS, pp. 22-34, doi: 10.1007/978-3-319-633121_3.

[6] S. S. Gornale and A. K. Babaleshwar, "Detection and Classification of Signage's from Random Mobile Videos Using Local Binary Patterns," Image, Graph. Signal Process., vol. 2, pp. 52-59, 2018, doi: 10.5815/ijigsp.2018.02.06.

[7] A. Azwar, "Integrasi Ekstraksi Fitur Local Binary Pattern dan Gray-Level Cooccurence Metriz untuk Pengenalan Ekspresi Mulut Pembelajar," IIk. J. IIm., vol. 9, no. 1, pp. 17-24, Apr. 2017, doi: 10.33096/ilkom.v9i1.105.17-24.

[8] A. Mahardika, Y. A. Sari, and C. Dewi, "Sistem Temu Kembali Citra Lubang Jalan Aspal Berdasarkan Tingkat Kerusakan Menggunakan Ekstraksi Fitur Gray Level Co-occurrence Matrix," J. Pengemb. Teknol. Inf. dan IImu Komput., vol. 2, no. 10, pp. 3811-3821, 2018.

[9] G. A. Pradnyana, I. K. A. Suryantara, and I. G. M. Darmawiguna, "Impression Classification of Endek (Balinese Fabric) Image Using K-Nearest Neighbors Method," Kinet. Game Technol. Inf. Syst. Comput. Network, Comput. Electron. Control, vol. 3, no. 3, pp. 213-220, Apr. 2018, doi: 10.22219/kinetik.v3i3.611.

[10] F. N. Achsani et al., "Deteksi Adanya Cacat Pada Kayu Menggunakan Metode Local Binary Pattern," e-Proceeding Eng., vol. 2, no. 1, pp. 298-305, 2015.

[11] B. Dwi Idestio and T. Agung Budi Wirayuda, "Alternative of Pothole Area Measurement Based-on Video using Threshold-based Marking and GLCM Alternatif Pengukuran Luas Lubang Jalan Berbasis Data Video Menerapkan Threshold-based Marking dan GLCM," Aug. 2014. doi: 10.14203/J.INKOM.235.

[12] H. Y. Sugandi, "Penerapan Metode RunLength dan Algoritma Simple Naive Bayes untuk Identifikasi Sidik Jari," J. Imiah Komput. dan Inform., vol. 5, no. 1, pp. 4554, 2016.

[13] D. Putra, Pengolahan Citra Digital, no. April. Yogyakarta: Penerbit Andi, 2010.

[14] M. S. Nixon and A. S. Aguado, Feature Extraction and Image Processing for Computer Vision. United States: Academic 
Press, 2020.

[15] R. Favoria Gusa, "Pengolahan Citra Digital Untuk Menghitung Luas Daerah Bekas Penambangan Timah," J. Nas. Tek. Elektro, vol. 2, no. 2, pp. 27-34, 2013, doi: 10.20449/jnte.v2i2.71.
[16] A. N. Fadhlillah, L. Novamizanti, and R. D. Atmaja, "Analisis Dan Implementasi Klasifikasi K-nearest Neighbor (k-nn) Pada Sistem Identifikasi Biometrik Telapak Kaki Manusia," eProceedings Eng., vol. 2, no. 2, 2015. 